Vol. 10, No.1, pp.16-23, 2022

Print ISSN: 2054-6297(Print)

Online ISSN: 2054-6300 (Online)

\title{
FULLY ONLINE E-LEARNING MODEL DEVELOPMENT AS AN ONLINE LEARNING MODEL DURING THE COVID-19 PANDEMIC
}

\author{
Komang Sugiarta \\ Accouting Departement, Bali State Polytechnic, Badung, Bali-Indonesia \\ Cening Ardina \\ Accouting Departement, Bali State Polytechnic, Badung, Bali-Indonesia \\ Komang Wiratama, \\ Electro Departement, Bali State Polytechnic, Badung,Bali-Indonesia
}

\begin{abstract}
During the Covid-19 pandemic, all teaching and learning activities at educational institutions were requested by the government to be carried out online. Therefore, there are no more learning activities carried out face-to-face in the classroom. This research was conducted to provide an overview of the online learning model in fully online e-learning with the blended learning method. By using this model, students do not need to open many platforms in carrying out learning activities. The innovation target to be achieved is the creation of an integrated online learning model in E-Learning at the Bali State Polytechnic Learning Management System. The method used in this research is development research design, starting from problem identification, model design, expert validation, and model testing. The data collected is qualitative data, namely the results of product quality assessments from experts and student responses. The data was collected by using a questionnaire, documentation, and observation. The results showed that the fully online e-learning model was feasible to be used as an online learning model. This is indicated by the results of the expert's assessment on the material and media aspect of $4(\mathrm{Good})$. Likewise, the results of student assessments showed an average score of 4 (Good).
\end{abstract}

KEYWORDS: model, learning, online, integrated.

\section{INTRODUCTION}

Along with the Covid-19 virus outbreak in Indonesia, all educational institutions are required by the government to adapt to new habits. In this case, universities should be able to organize online learning using a structured and integrated Learning Management System (DitjenDikti Kemdikbud RI). Likewise, the Bali State Polytechnic must also make adaptations in the implementation of teaching and learning activities, namely from face-to-face learning in class to online from home. However, in reality only 3 lecturers in the accounting department use the Learning Management System in conducting online learning. The platforms used are also different, so students have to open many application programs in participating in learning activities. This causes the learning process to be inefficient, because students must follow the platform used by the lecturer. In addition, the activities of lecturers and students in the teaching and learning process cannot be monitored by institutional leaders, because they are not recorded in the Learning Management System of the Bali State Polytechnic. Based on these problems, it is very necessary to do 
research on online learning models that are integrated in the Learning Management System.

The learning model is a conceptual framework that describes a systematic procedure for organizing learning experiences to achieve certain learning objectives, and serves as a guide for designer learners and teachers in planning and implementing learning activities (Winaputra, 2005). Online learning is learning that uses multimedia technology, virtual classrooms, CD ROMs, video streaming, voice messages, email and telephone conferences, animated online text, and online video streaming (Thorne, 2003). E-Learning is a broad set of applications and processes which include web based learning, computer-based learning, virtual and digital classrooms. Much of this is delivered via the Internet, intranets, audio and videotape, satellite broadcast, interactive TV, and CD-ROM. The definition of e-learning varies depending on the organization and how it is used but basically it is involving electronic means of communication, education, and training (The American Society for Training and Development, 2012).

Application that is widely used in designing E-learning on a Learning Management System is Moodle (Modular Object Oriented Dynamic Learning Environment). Moodle is a website-based e-Learning application that can convert offline learning media into online learning media (web based). With the Moodle application, lecturers can present various learning materials such as quizzes, assignments, and others online. In addition, students can also access learning materials provided online.

According to Nedelko (2008), there are three forms of e-learning that can be applied in online learning, namely:

1. Web Supported e-learning, is learning that is still carried out face-to-face and is supported by the use of websites that contain learning objectives, materials, assignments, and short tests.

2. Blended or mixed mode e-learning, is that part of the learning process is done face-to-face and partly done online.

3. Fully online e-learning format, is that the entire learning process is carried out online, including faceto-face meetings between educators and students, which is also carried out online using teleconference.

In this study, the fully online e-learning model will be used in developing an online learning model at the Bali State Polytechnic.

\section{METHOD}

This research was conducted at the Department of Accounting, Bali State Polytechnic. The research activities started from problem identification, model design, expert validation, and testing. Problem identification was collected from the results of monitoring the implementation of the online teaching and learning process that had been carried out previously. The model design is prepared using a fully online e-learning model that is integrated into the Bali State Polytechnic Learning Management System. Expert validation is carried out to get an expert's assessment of the resulting online learning model. The trial was conducted to test the applicability of this online learning model.

\section{FINDINGS AND DISCUSSION}

The E-Learning model in the Bali State Polytechnic Learning Management System is as shown in Figure 1. 


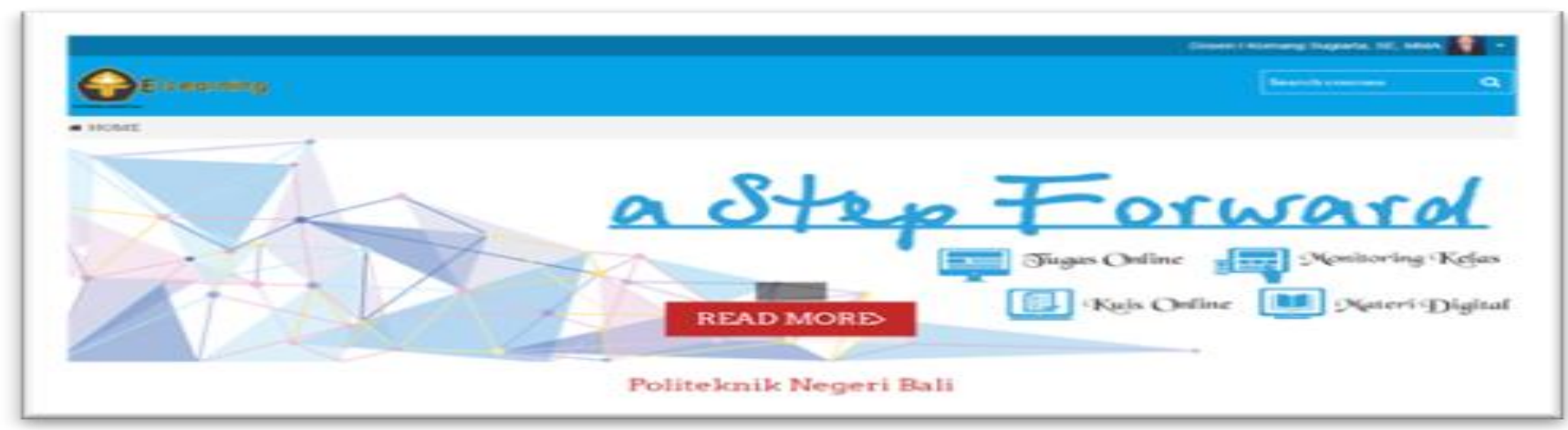

Figure 1. Bali State Polytechnic E-Learning.

The implementation of the teaching and learning process in the Accounting Department during the Covid-19 pandemic has all been carried out online. In this case, the media or platforms used in online learning activities are Whatsapp, Google meet, Google Classroom, and Youtube. Only 3 lecturers in the accounting department used the Bali State Polytechnic E-Learning. The reason they don't use ELearning is the limited features available and the late enrollment of courses. In this case, there is no Attendance feature to fill attendance and Meeting for face-to-face lectures. This limitation is caused by the unavailability of facilities to install plugins on Moodle. Even though the government hopes that during the Covid-19 pandemic, every university can hold online learning using a structured and integrated Learning Management System (Ditjen Dikti Kemdikbud RI, 2020).

Based on these problems, an integrated online learning model will be created in the Bali State Polytechnic Learning Management System. This model was developed by implementing the Lesson feature to fill student attendance, integrating Google Meet for face-to-face lectures and others. Thus, all activities in online learning can be carried out on E-Learning. The output of this research is an integrated online learning model using the Bali State Polytechnic E-Learning. This model has been tested in class 2B Diploma 4 Managerial Accounting in learning the Practicum Fundamentals of Accounting course in the even semester of 2020/2021. The form of display and how to use it is as follows.

A. The display of integrated online learning model.

1. Display of Lesson Plan information at the beginning of the course page as shown in Figure 2.

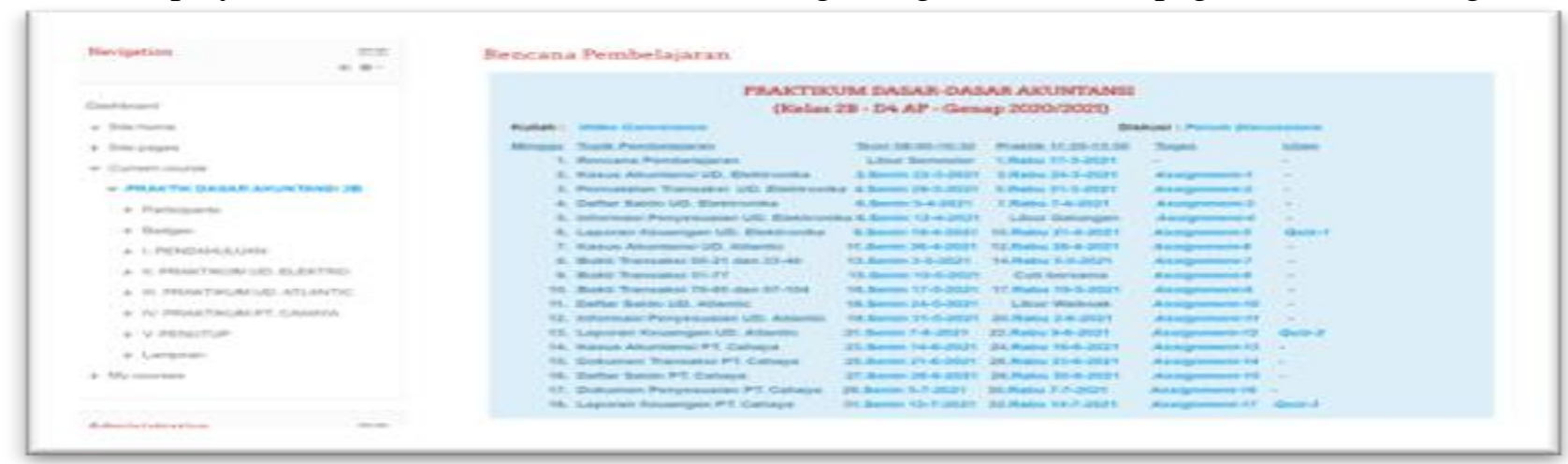

Figure 2. Lesson Plan Information.

2. Display of Learning Objectives and Materials in each section as shown in Figure 3. 
International Journal of Education, Learning and Development

Vol. 10, No.1, pp.16-23, 2022

Print ISSN: 2054-6297(Print)

Online ISSN: 2054-6300 (Online)

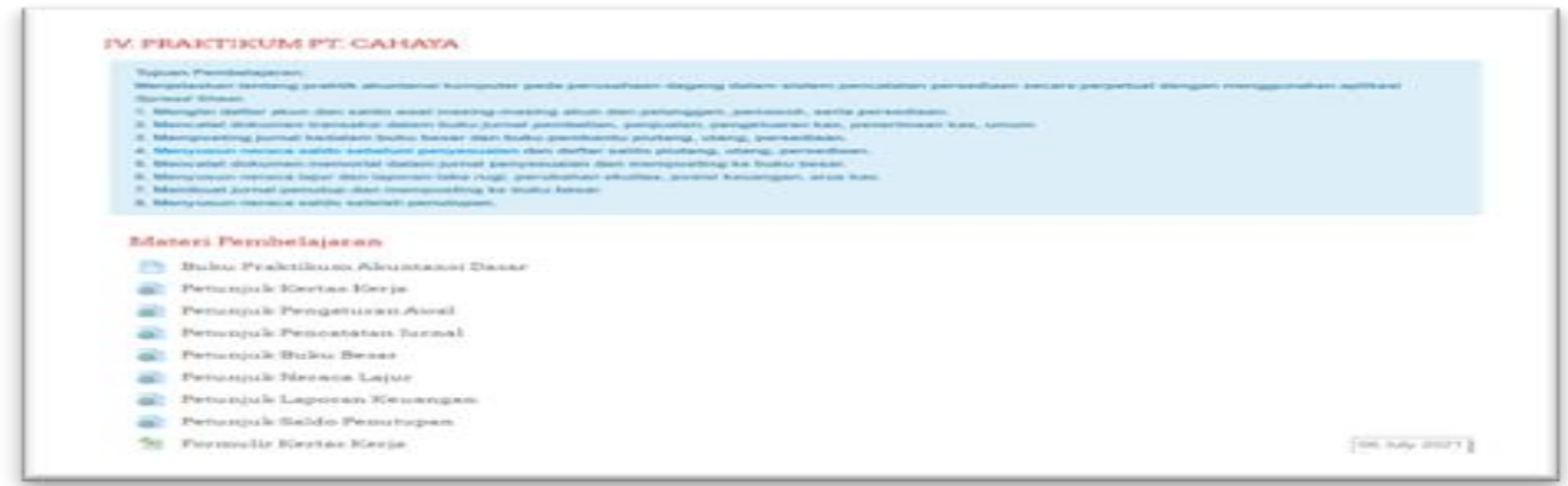

Figure 3. Learning Objectives and Materials.

3. Display of Learning Activities and Evaluation in each section as shown in Figure 4.

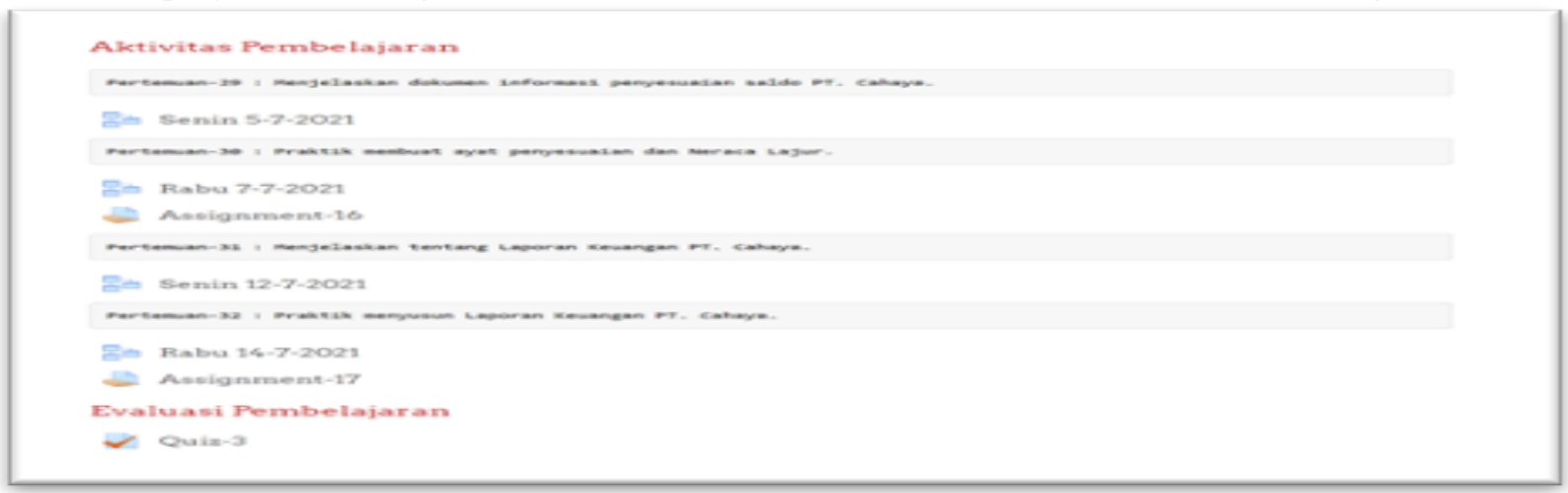

Figure 4. Learning Activities and Evaluation.

B. The use of an integrated online learning model.

1. To give face-to-face lecture, click Video Conference on the lesson plan screen, so that the google meet platform that has been created on the google calendar will open according to the class schedule, which is as shown in Figure 5.

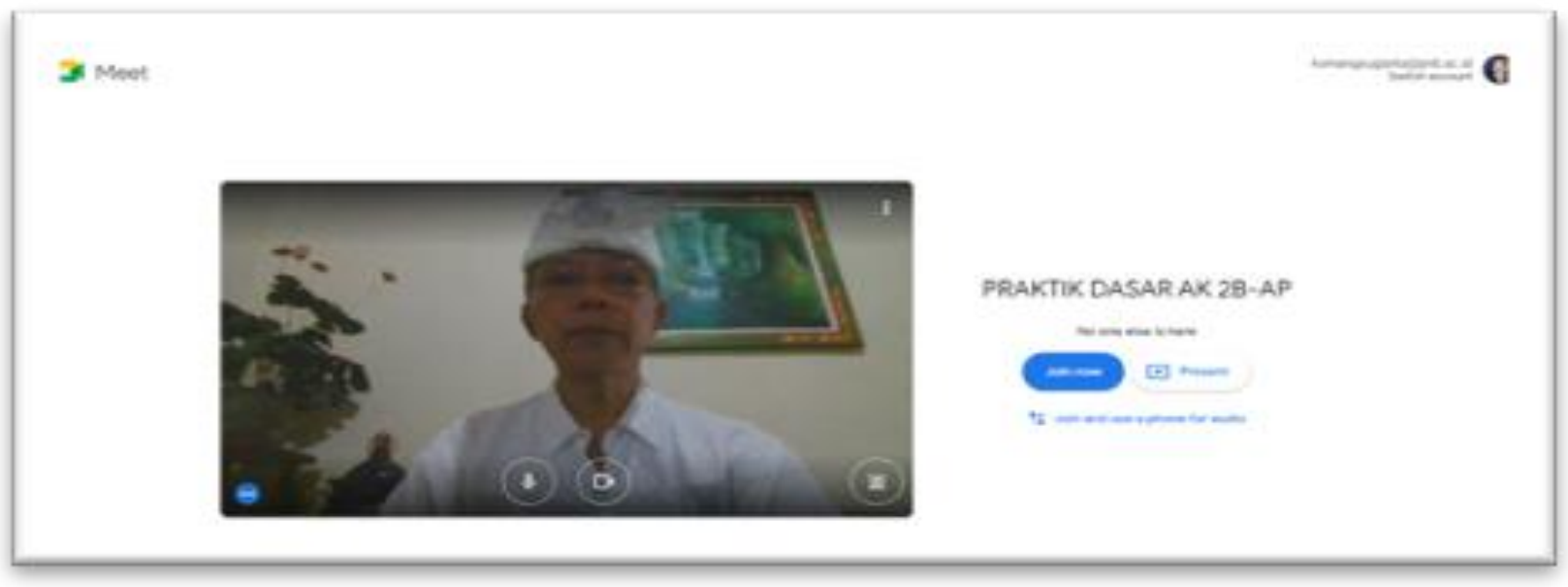

Figure 5. Face-to-face Lecture.

2. To conduct a discussion forum, click Forum Discussions on the lesson plan screen, so that a discussion room is opened as shown in Figure 6. 
International Journal of Education, Learning and Development

Vol. 10, No.1, pp.16-23, 2022

Print ISSN: 2054-6297(Print)

Online ISSN: 2054-6300 (Online)

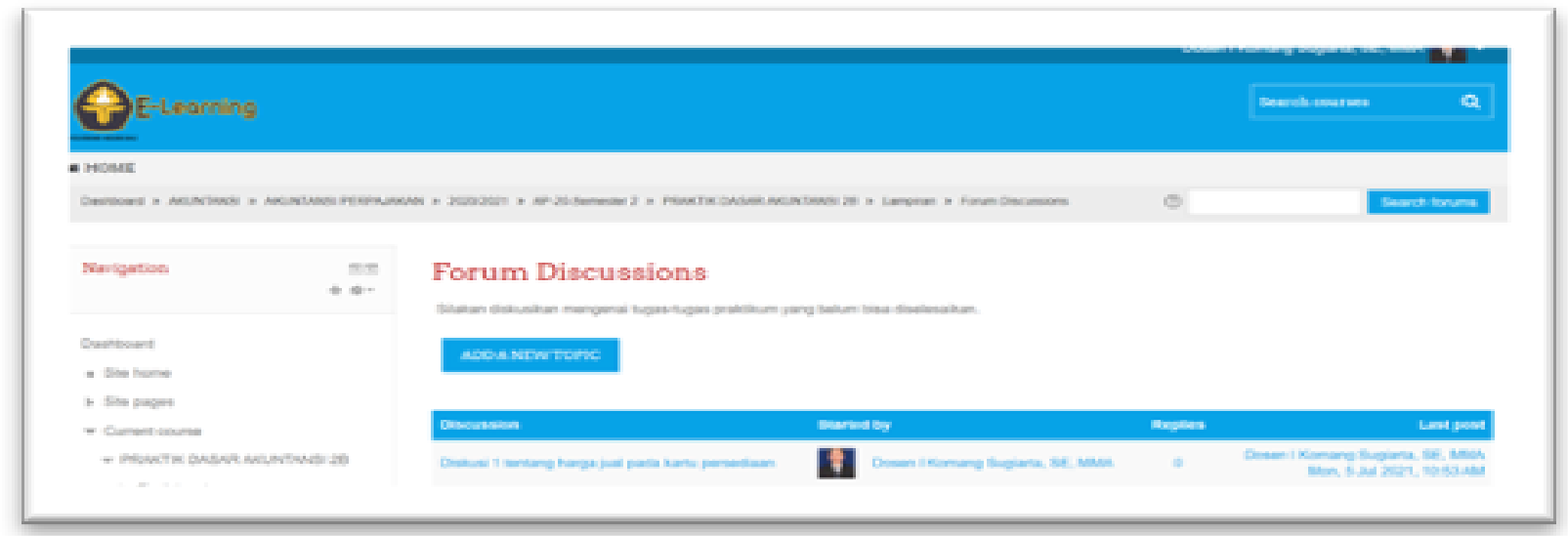

\section{Figure 6. Discussion Forum Activities.}

3. To fill in the attendance form, click The date of the class schedule on the lesson plan screen, so that the attendance form appears as shown in Figure 7.

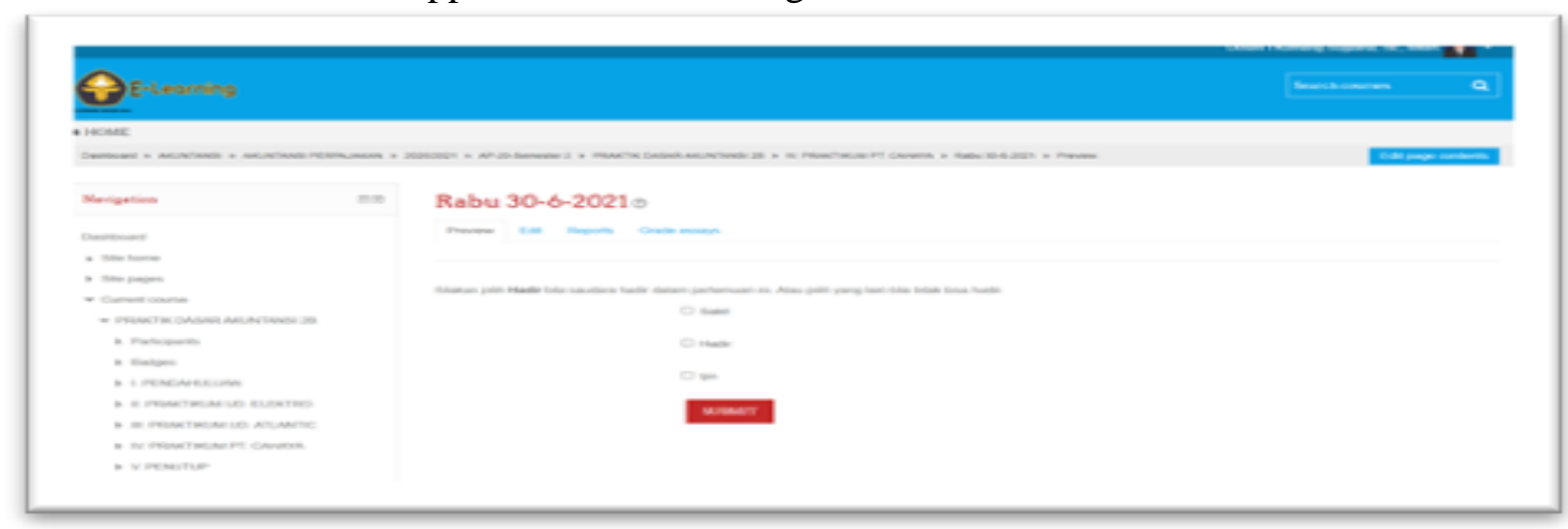

\section{Figure 7. Attendance Form.}

To view the attendance list, click reports, so that the report appears as shown in Figure 8.

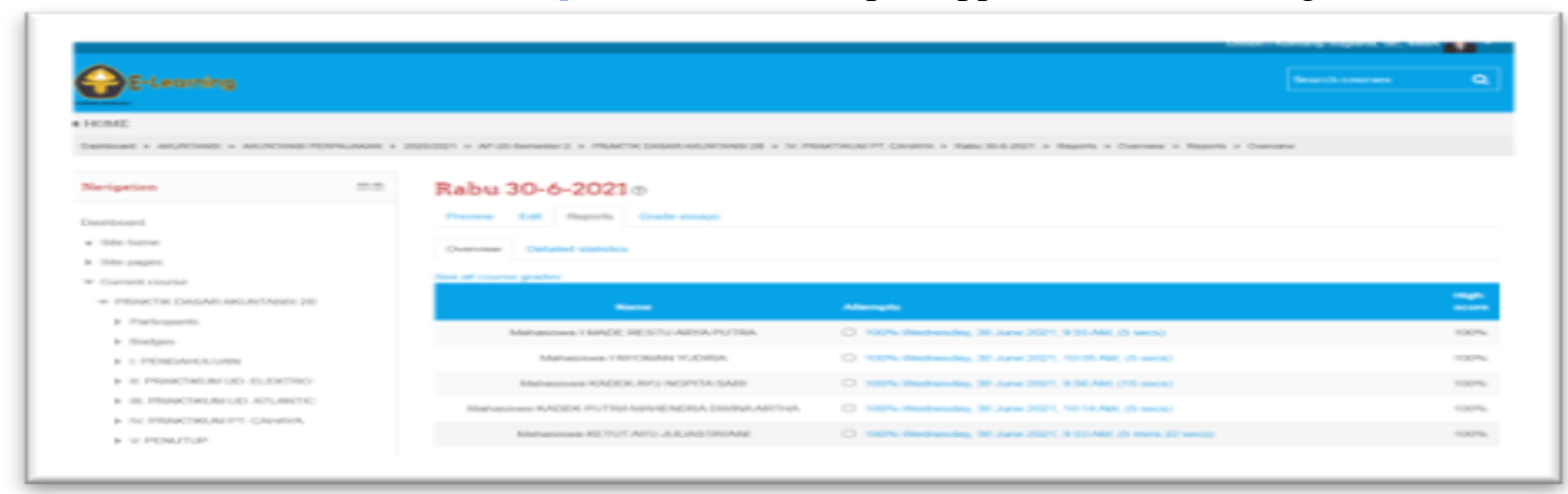

Figure 8. List of Attendance. 
International Journal of Education, Learning and Development

Vol. 10, No.1, pp.16-23, 2022

Print ISSN: 2054-6297(Print)

Online ISSN: 2054-6300 (Online)

4. To give assignments or exercises, click Assignment according to the class schedule on the learning plan screen, so you can see the job descriptions and the number of students who send assignments as shown in Figure 9.

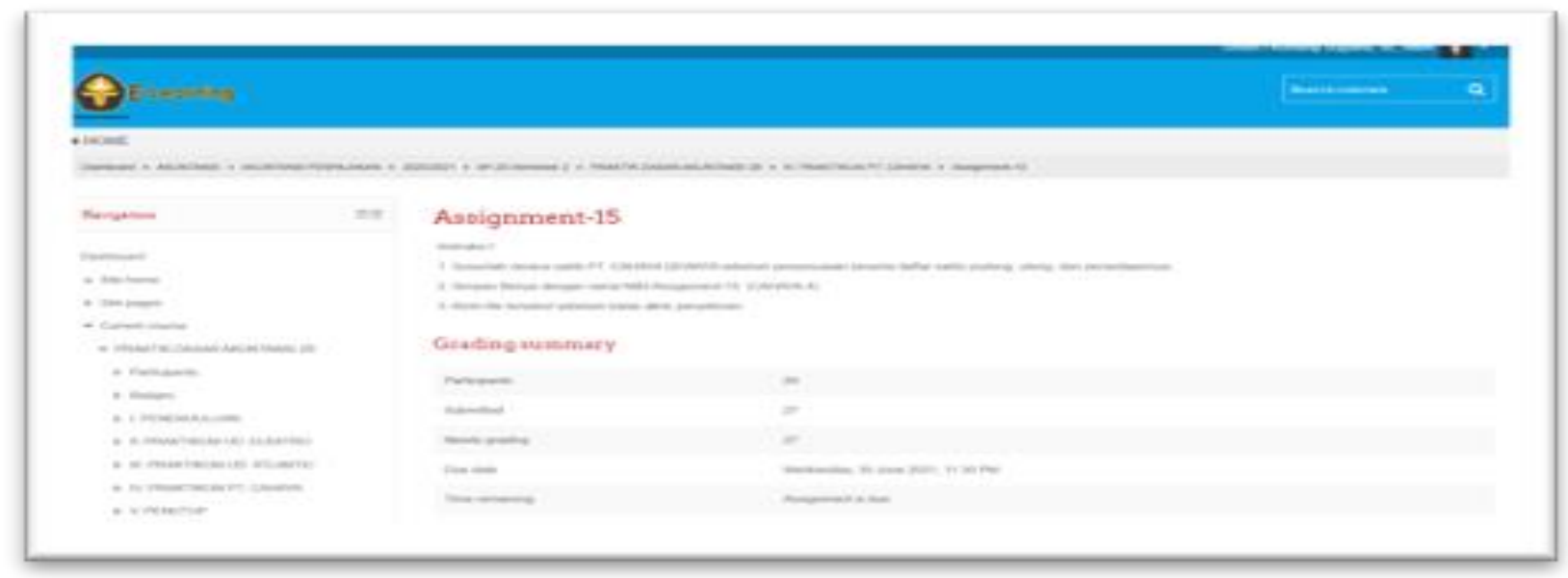

\section{Figure 9. Student Assignments.}

To see students who have sent assignments, click view, so that the student name and assignment file appear as shown in Figure 10.

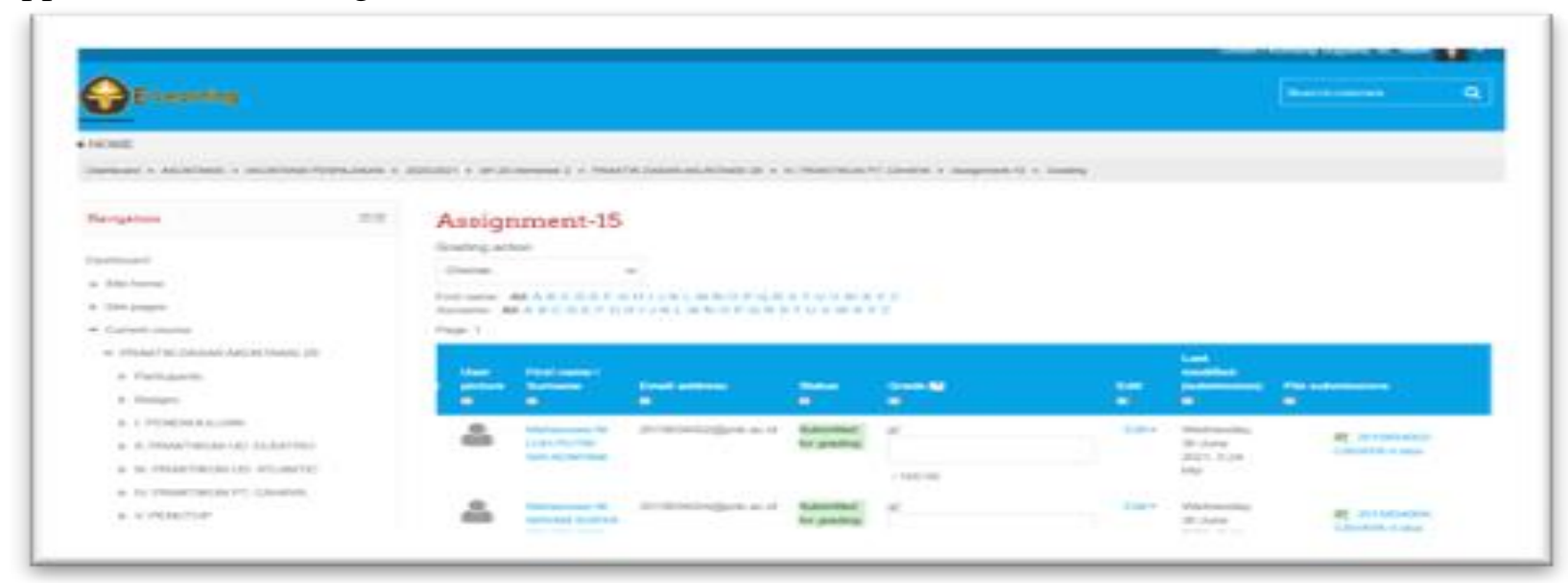

Figure 10. List of Student Assignments.

5. To give a test, click Quiz according to the part that will be tested on the lesson plan screen, so you can see the test instructions as shown in Fig. 11. 


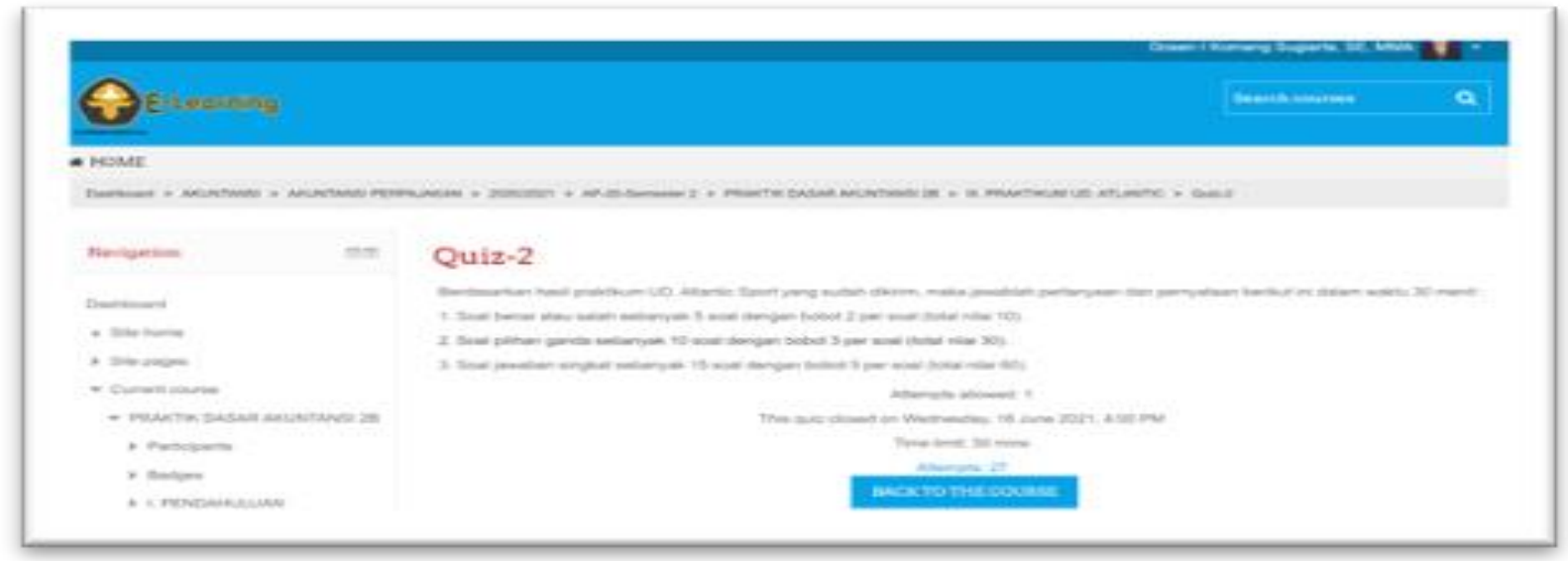

Figure 11. Test Description.

To see the value of the test results, click the Result menu, so that the test scores appear as shown in the picture 12.

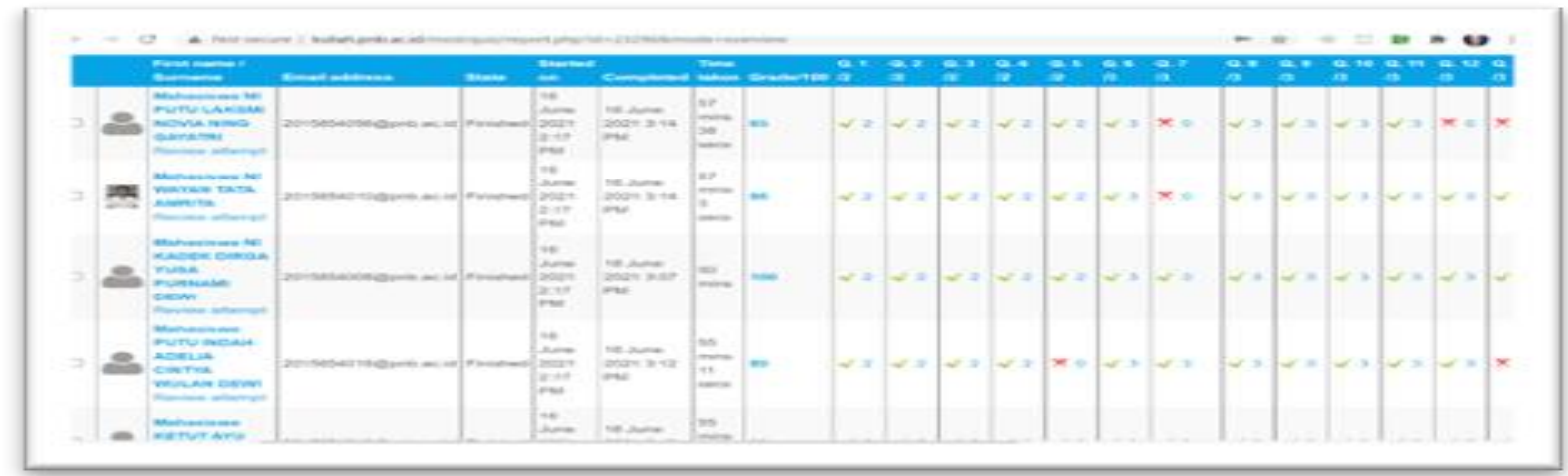

Figure 12. List of Test Values.

\section{CONCLUSION}

Based on the results of these studies, it can be concluded as follows:

1. The online learning model at the Bali State Polytechnic can be designed using the Fully Online E-learning model, where all learning activities can be carried out online.

2. The learning model can be design by integrating Google Meet in the Bali State Polytechnic ELearning, so that learning activities can be carried out through 1 platform

3. The learning method used is Blended Learning, where student assignments are carried out online and face-to-face lectures are carried out virtually using video conferences that have been integrated in the Learning Management System.

Suggestions that can be submitted as recommendations to the leadership of the Bali State Polytechnic are:

1. The Moodle version used by the Bali State Polytechnic should be upgraded to a new version, so that if there is a need for additional features, time zone and language adjustments can be done easily. 
Vol. 10, No.1, pp.16-23, 2022

Print ISSN: 2054-6297(Print)

Online ISSN: 2054-6300 (Online)

2. During the Covid-19 pandemic, the Bali State Polytechnic should be able to organize online learning using the existing Learning Management System, in accordance with the recommendations of the Indonesian Ministry of Education and Culture.

\section{REFERENCES}

Alessi, S.M. \& Trollip, S.R. 2001. Multimedia for Learning: Methods and Development. ( $3^{\text {rd }}$ Ed). Boston MA: Allyn and Bacon, Inc.

Bersin, J. 2004. The Blended Learning Book: Best Practices, Proven Methodologies, and Lessons Learned. San Francisco, CA: Pfeiffer.

Budiarso, D. E. Anies. 2008. Development of Moodle-Based E-Learning as an Alternative Learning Model and Supporting Lectures in the Department of Curriculum and Educational Technology. Semarang: Unnes.

Borg,W.R., Gall, M.D., \& Gall, J.P. 2003. Educational research. An introduction. (7 ${ }^{\text {th }}$ ed.). New York: Longman.

Clark, R. C. dan Mayer, R. E. 2003. E-Learning and the science of instruction. San Fransisco: JossyBass/Pfeiffer.

Ghirardini, B. 2011. E-learning Methodologies. Germany: Federal Ministry of Food, Agriculture and Cunsomer Protection.

Directorate General of Higher Education, Ministry of Education and Culture RI. 2020. Guidebook for the Implementation of Odd Semester 2020/2021 Learning in Higher Education.

Harry B. Santoso. 2008. e-Learning: Learn Anytime, Anywhere.

Kemendikbud. 2020. Circular No. 4 of 2020 concerning the Implementation of Educational Policies During the Islamic Emergency Period and Spread of CORONAVIRUS DISESASE (Covid19).

Kuntarto E. 2017. The Effectiveness of Online Learning Models in Indonesian Language Lectures in Higher Education. Journal Indonesian Language Education and Literature Vol. 3 No. 1.

Nedelko, Zlatko. 2008. Participants' Characteristics for E-Learning. http://www.g-cass.com.

Permana, 2009. E-Learning, Online Learning Management System. Bandung: UPI.

Prasetio, dkk. 2012. Design and Implementation of Online Learning Content With Blended Learning Method. Journal of Electrical Engineering, UNSRAT

Rusman. 2012. Learning Models. Jakarta : Grasindo.

Rimbarizki R. and Susilo H. 2017. Application of Combination Online Learning in Improving Students' Learning Motivation in Vocational Package $\mathrm{C}$ at the Karanganyar Pioneer Community Learning Activity Center. E-Journal Unesa.

Siahaan, S. 2003. E-learning as an alternative learning activity. Journal of Education and Culture.

Stockley, D. 2012. E-Learning Definition and Explanation. http://derekstock ley.com.au/elearningdefinition.html

Sugiyono. 2016. Quantitative, Qualitative, and R\&D Research Methods, Twenty-fourth edition. Bandung: Alfabeta.

The American Society for Training and Development (ASTD). 2012. Definition of eLearning. http://www.about-elearning.com/definition-ofelearning.html

Thorne, K. 2003. Blended Learning: How to Integrate Online \& Traditional Learning. London \& Sterling, VA: Kogan Page Limited.

Trianto. 2010. Constructivistic Oriented Innovative Learning Models. Jakarta: Library Achievement.

Winataputra, U.S. 2005. Teaching in College : Innovative Learning Models. Jakarta : Open University. 